\title{
GAS EXCHANGE, CHLOROPLAST PIGMENTS AND GROWTH OF PASSION FRUIT CULTIVATED WITH SALINE WATER AND POTASSIUM FERTILIZATION ${ }^{1}$
}

\author{
GEOVANI SOARES DE LIMA ${ }^{2 *}$, COSMO GUSTAVO JACOME FERNANDES ${ }^{2}$, LAURIANE ALMEIDA DOS ANJOS \\ SOARES $^{2}$, HANS RAJ GHEYI ${ }^{3}$, PEDRO DANTAS FERNANDES ${ }^{4}$
}

\begin{abstract}
The objective of this study was to evaluate the gas exchange, chloroplast pigments and growth of 'BRS Rubi do Cerrado' passion fruit as a function of irrigation with saline water and potassium fertilization in the seedling formation stage. The experiment was conducted under greenhouse conditions in the municipality of Pombal-PB, Brazil. A randomized block design was used in $5 \times 2$ factorial scheme, corresponding to five levels of water electrical conductivity - ECW $\left(0.3,1.1,1.9,2.7\right.$ and $\left.3.5 \mathrm{dS} \mathrm{m}^{-1}\right)$ and two doses of potassium - KD (50 and 100\% of the recommendation), with four replicates and two plants per plot. Water salinity from $0.3 \mathrm{dS} \mathrm{m}^{-1}$ reduced the stomatal opening, transpiration, $\mathrm{CO}_{2}$ assimilation and inhibited the growth of 'BRS Rubi do Cerrado' passion fruit plants, at 40 days after sowing. There was no $\mathrm{CO}_{2}$ restriction in the substomatal cavity of passion fruit plants grown under water salinity from $0.3 \mathrm{dS} \mathrm{m}^{-1}$. Potassium dose of $150 \mathrm{mg} \mathrm{kg}^{-1}$ of soil, corresponding to $100 \%$, intensified the effect of salt stress on the assimilation rate and instantaneous carboxylation efficiency in 'BRS Rubi do Cerrado' passion fruit. There was interaction between water salinity levels and potassium doses for the chlorophyll $a$ and $b$ contents of 'BRS Rubi do Cerrado' passion fruit.
\end{abstract}

Keywords: Salt stress. Potassium. Osmoregulation.

\section{TROCAS GASOSAS, PIGMENTOS CLOROPLASTÍDICOS E CRESCIMENTO DO MARACUJAZEIRO CULTIVADO COM ÁGUAS SALINAS E ADUBAÇÃO POTÁSSICA}

\begin{abstract}
RESUMO - Objetivou-se com este trabalho avaliar as trocas gasosas, os pigmentos cloroplastidicos e o crescimento do maracujazeiro 'BRS Rubi do Cerrado' em função da irrigação com águas salinas e adubação potássica, na fase de formação de mudas. O experimento foi conduzido sob condições de casa-de-vegetação no município de Pombal-PB. Foi utilizado o delineamento de blocos casualizados em esquema fatorial $5 \times 2$, sendo cinco níveis de condutividade elétrica da água - $\mathrm{CEa}\left(0,3 ; 1,1 ; 1,9 ; 2,7\right.$ e $\left.3,5 \mathrm{dS} \mathrm{m}^{-1}\right)$ e duas doses de potássio - DK (50 e 100\% da recomendação) com quatro repetições e duas plantas por parcela. A salinidade da água a partir de $0,3 \mathrm{dS} \mathrm{m}^{-1}$ diminuiu a abertura estomática, a transpiração, a assimilação de $\mathrm{CO}_{2} \mathrm{e}$ inibiu o crescimento das plantas de maracujazeiro 'BRS Rubi do Cerrado', aos 40 dias após o semeio. Não houve restrição de $\mathrm{CO}_{2}$ na cavidade subestomática das plantas de maracujazeiro cultivadas sob salinidade da água a partir de $0,3 \mathrm{dS} \mathrm{m}^{-1}$. A dose de potássio de $150 \mathrm{mg} \mathrm{kg}^{-1}$ de solo, correspondente a $100 \%$, intensificou o efeito do estresse salino sobre a taxa de assimilação e a eficiência instantânea de carboxilação no maracujazeiro 'BRS Rubi do Cerrado'. Houve interação entre os níveis salinos da água e as doses de potássio para os teores de clorofila $a$ e $b$ do maracujazeiro 'BRS Rubi do Cerrado'.
\end{abstract}

Palavras-chave: Estresse salino. Potássio. Osmorregulação.

\footnotetext{
"Corresponding author

${ }^{1}$ Received for publication in $06 / 27 / 2019$; accepted in 12/26/2019.

${ }^{2}$ Academic Unit of Agricultural Sciences, Universidade Federal de Campina Grande, Pombal, PB, Brazil; geovani.soares@pq.cnpq.br ORCID: 0000-0001-9960-1858, gustavo.lg2014@gmail.com - ORCID: 0000-0003-1056-3782, lauriane.soares@pq.cnpq.br - ORCID: 0000-0002-7689-9628.

${ }^{3}$ Nucleus of Soil and Water Engineering, Universidade Federal do Recôncavo da Bahia, Cruz das Almas, BA, Brazil; hans@pq.cnpq.br ORCID: 0000-0002-1066-0315.

${ }^{4}$ Academic Unit of Agricultural Engineering, Universidade Federal de Campina Grande, Campina Grande, PB, Brazil; pedrodantasfernandes@gmail.com -ORCID: 0000-0001-5070-1030.
} 


\section{INTRODUCTION}

Belonging to the Passifloraceae family, passion fruit stands out as one of the most cultivated species. In the 2018 season, Brazil stood out as the world's largest passion fruit producer, with an area of approximately 78,502.42 hectares, resulting in the production of 602,651 tons per year. Passion fruit cultivation is carried out in almost all Brazilian states, especially in the Northeast region, which has the largest planted area, where the states of Bahia and Ceará have 15,724 and 6,862 hectares of plantations, with average yields of 10.50 and $17.25 \mathrm{t} /$ ha, respectively (IBGE, 2018).

However, passion fruit production in regions with low water availability, such as in the semiarid region of northeastern Brazil, causes large variations in its production cycle (ODRESCA, 2016). At the same time, the quality of irrigation water in these regions has deteriorated, especially due to increased salt concentrations. In addition, soil salinization combined with inadequate irrigation management is becoming increasingly harmful to agriculture (AREF; RAD, 2012).

Passion fruit irrigation with saline water has been investigated in several studies (DIAS et al., 2012; FREIRE et al., 2012; VIANA et al., 2012). In general, these studies have shown that salinity reduces the growth of branches and several other growth components, besides compromising some chemical characteristics of the fruits when irrigation is carried out with waters of moderate to high salinity. These limitations occur because, under saline conditions, there is a reduction in water availability to plants, due to the reduction in the osmotic potential of the soil solution (JIANG et al., 2012). In addition, salinization leads to nutritional imbalance since excess sodium in the soil solution causes disorder in nutrient absorption, affecting the concentrations of ions such as $\mathrm{Ca}, \mathrm{Mg}$ and $\mathrm{K}$ in the plant (MARSCHNER, 2012).

However, plants have developed a wide range of mechanisms to withstand a variety of stress conditions. Evidence indicates that mineral nutrients, particularly potassium, play a key role in plant resistance to salt stress, and such tolerance to salinity is directly associated with the content of $\mathrm{K}^{+}$due to its involvement in osmotic regulation and competition with $\mathrm{Na}^{+}$(MARSCHNER, 2012).

Potassium acts directly on passion fruit growth and production, as the main functions of this nutrient in the plant are related to many physiological processes, such as carbon assimilation, photosynthesis, protein synthesis, enzymatic activation, stomatal movement and translocation of organic and inorganic nutrients from soil to plant (ZHANG et al., 2010). In addition, in the metabolism it is involved in the activation of the synthesis of starch, phosphate, sucrose and other enzymes, and in transport of carbohydrates. Under salt stress, K helps maintain ionic homeostasis and improves plant antioxidant defense, protecting it from oxidative stress (HASANUZZAMAN et al., 2018).

Therefore, there is a need for more accurate research with passion fruit crop irrigated with saline water in the Northeast region, in order to evaluate the deleterious effects of salt stress on this species, as well as to enable the adoption of agronomic strategies, such as potassium fertilization, aiming at an adequate management for the crop under the conditions of the northeastern semiarid region.

In this context, the objective of this study was to evaluate the gas exchange, chloroplast pigments and growth of 'BRS Rubi do Cerrado' passion fruit as a function of irrigation with saline water and potassium fertilization, in the seedling formation stage.

\section{MATERIAL AND METHODS}

The experiment was carried out from March to May 2019 in a protected environment (greenhouse) of the Center for Sciences and AgriFood Technology - CCTA of the Federal University of Campina Grande - UFCG, located in the municipality of Pombal, Paraíba, PB, Brazil $\left(6^{\circ} 47^{\prime} 20^{\prime \prime} \mathrm{S}\right.$ latitude and $37^{\circ} 48^{\prime} 01^{\prime \prime} \mathrm{W}$ longitude; altitude of $194 \mathrm{~m})$.

The treatments resulted from the combination of five salt concentrations in the irrigation water expressed through the electrical conductivity - ECW $\left(0.3 ; 1.1 ; 1.9 ; 2.7\right.$ and $\left.3.5 \mathrm{dS} \mathrm{m}^{-1}\right)$ associated with two doses of potassium fertilization - KD (50 and $100 \%$ of the recommendation of $\mathrm{K}_{2} \mathrm{O}$ ) according to Novais, Neves and Barros (1991). The experimental design was randomized blocks in a $5 \times 2$ factorial arrangement, with two plants per plot and four replicates, totaling eighty experimental units. The potassium dose relative to $100 \%$ of the recommendation corresponded to $150 \mathrm{mg} \mathrm{K}_{2} \mathrm{O} \mathrm{kg}$ of soil.

Seeds of 'BRS Rubi do Cerrado' passion fruit were used in this study. This cultivar has red- or purplish-peel fruits weighing 120 to 300 grams (average of $170 \mathrm{~g}$ ), with soluble solids content of 13 to $15{ }^{\circ}$ Brix (average of $14{ }^{\circ}$ Brix) and juice yield around $35 \%$. Higher levels of resistance to the main diseases of passion fruit (viral disease, bacterial disease, anthracnose and scab) and high levels of yield are the two most important characteristics of this cultivar (EMBRAPA, 2012).

In order to obtain passion fruit seedlings, sowing was performed by placing 2 seeds in polyethylene bags with dimensions of $15 \times 30 \mathrm{~cm}$, at $1.5 \mathrm{~cm}$ depth and equidistantly distributed (Figure 1A), supported on benches at $0.8 \mathrm{~m}$ height from the soil. The bags were filled with a 2:1:1 ratio of sandy loam Entisol, sand and organic matter (well-aged bovine manure), from the rural area of the 
municipality of São Domingos, PB, whose chemical and physical characteristics (Table 1) were obtained according to the methodology proposed by Donagema et al. (2011).

All fertilizations were performed as topdressing, according to the recommendation for fertilization in pot experiments contained in Novais, Neves and Barros (1991), using the amounts of 100 and $300 \mathrm{mg} \mathrm{kg}^{-1}$ of soil of nitrogen and phosphorus $\left(\mathrm{P}_{2} \mathrm{O}_{5}\right)$, respectively, in the form of Monoammonium
Phosphate (MAP), applied via irrigation water at 15 and 30 days after sowing (DAS). Potassium fertilization was split into portions applied via fertigation, at 10-day intervals, in quantities of 75 and $150 \mathrm{mg}$ of $\mathrm{K}_{2} \mathrm{O} \mathrm{kg}^{-1}$ of soil in each container for the treatments $\mathrm{K}_{1}$ and $\mathrm{K}_{2}$, respectively, using potassium chloride as a source, and the $\mathrm{K}_{2}$ dose corresponded to $100 \%$ of the recommendation of Novais, Neves and Barros (1991).

Table 1. Chemical and physical characteristics of the soil used in the experiment.

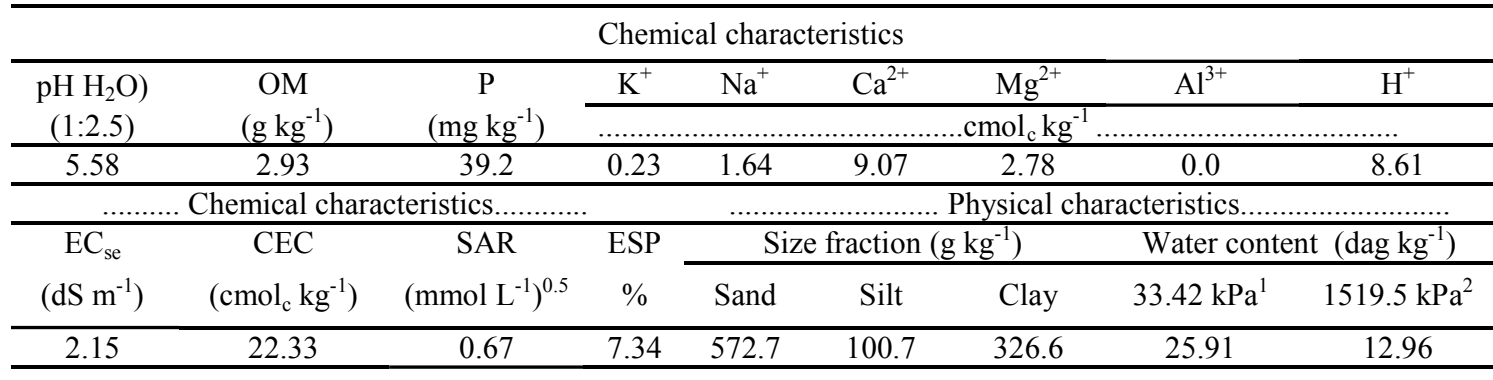

$\mathrm{pH}$ - Hydrogen potential, OM - Organic matter: Walkley-Black Wet Digestion; $\mathrm{Ca}^{2+}$ and $\mathrm{Mg}^{2+}$ extracted with $1 \mathrm{M}$ $\mathrm{KCl}$ at $\mathrm{pH} 7.0 ; \mathrm{Na}^{+}$and $\mathrm{K}^{+}$extracted with $1 \mathrm{M} \mathrm{NH}_{4} \mathrm{OAc}$ at $\mathrm{pH} 7.0 ; \mathrm{Al}^{3+}+\mathrm{H}^{+}$extracted with $0 . \mathrm{a} 5 \mathrm{M} \mathrm{CaOAc}$ at $\mathrm{pH}$ 7.0; ECse - Electrical conductivity of the saturation extract; CEC - Cation exchange capacity; SAR - Sodium adsorption ratio of the saturation extract; ESP - Exchangeable sodium percentage; ${ }^{1,2}$ referring to field capacity and permanent wilting point.

The water used for irrigation in the treatment of lowest salinity $\left(0.3 \mathrm{dS} \mathrm{m}^{-1}\right)$ came from the public supply system of Pombal, PB, whereas the other salinity levels were prepared in such a way to have an equivalent proportion of 7:2:1 for $\mathrm{Na}: \mathrm{Ca}: \mathrm{Mg}$, respectively, from the salts $\mathrm{NaCl}, \mathrm{CaCl}_{2} \cdot 2 \mathrm{H}_{2} \mathrm{O}$ and $\mathrm{MgCl}_{2} \cdot 6 \mathrm{H}_{2} \mathrm{O}$, a ratio that prevails in sources of water used for irrigation in small properties of northeastern Brazil.

Irrigation waters of the highest salinity levels were prepared considering the relationship between $\mathrm{ECW}$ and salt concentration $\left(\mathrm{mmol}_{\mathrm{c}} \mathrm{L}^{-1}=10 * \mathrm{ECW}\right.$ $\left(\mathrm{dS} \mathrm{m}^{-1}\right)$ ), according to Richards (1954), checking the values with a conductivity meter (reading adjusted to temperature of $25^{\circ} \mathrm{C}$ ). After preparation, the waters were stored in 80 -L plastic containers, one for each $\mathrm{ECW}$ level studied, properly protected to avoid evaporation, entry of rainwater and contamination with materials that may compromise their quality.

After sowing, irrigation was performed daily at 17:00 h, applying in each container the volume corresponding to that obtained by the water balance, based on the volume consumed (VC), considering the water volume applied to plants (VA) in the previous day; VD is the volume drained, quantified in the morning of the next day and the desired leaching fraction - LF (20\%), in order to avoid excessive accumulation of salts from irrigation water in the root zone.

At 40 DAS, the following gas exchange variables were evaluated: stomatal conductance $(g s)$ $\left(\mathrm{mol} \mathrm{m} \mathrm{m}^{-2} \mathrm{~s}^{-1}\right)$, transpiration $(E)\left(\mathrm{mmol} \mathrm{H}_{2} \mathrm{O} \mathrm{m}^{-2} \mathrm{~s}^{-1}\right)$,
$\mathrm{CO}_{2}$ assimilation rate $(A)\left(\mu \mathrm{mol} \mathrm{m} \mathrm{m}^{-2} \mathrm{~s}^{-1}\right)$ and internal $\mathrm{CO}_{2}$ concentration $(\mathrm{Ci})\left(\mu \mathrm{mol} \mathrm{mol}{ }^{-1}\right)$. These data were then used to estimate intrinsic water use efficiency (WUEi) - A/gs ( $\mu \mathrm{mol} \mathrm{CO}_{2} \mathrm{~mol} \mathrm{H}_{2} \mathrm{O}^{-1}$ ), instantaneous carboxylation efficiency (CEi) - $\mathrm{A} / \mathrm{Ci}$ $\left(\mu \mathrm{mol} \mathrm{m} \mathrm{m}^{-2} / \mu \mathrm{mol} \mathrm{m} \mathrm{s}^{-1}\right)$. Such measurements were performed with a gas exchange meter for plants, containing an infrared gas analyzer - IRGA (Infrared Gas Analyser, LCpro - SD model), from ADC BioScientific, UK. The procedure for measuring the respective variables was performed by adopting as a criterion the third fully expanded leaf counted from the apical bud.

Chlorophyll $a$, chlorophyll $b$, and carotenoid contents were determined in samples of 5 discs of the lamina of the third mature leaf from the apex, as indicated in the methodology proposed by Arnon (1949). From the extracts, the concentrations of these compounds in the solutions were measured using a spectrophotometer at the absorbance (ABS) wavelength $(470,646$, and $663 \mathrm{~nm})$, according to the following equations (Equations 1, 2 and 3):

$$
\begin{aligned}
& \text { Chl } a=12.21 \text { ABS663 }-2.81 \text { ABS646 } \\
& \text { Chl } b=20.13 \text { A646-5.03 ABS663 } \\
& \text { Car }=(1000 \text { ABS470 - } 1.82 \text { Cla-85.02 Clb }) / 198
\end{aligned}
$$

Where: Chl $a=$ Chlorophyll $a$; Chl $b=$ Chlorophyll $b$; and Car $=$ Total carotenoids. The values obtained for chlorophyll $a$, chlorophyll $b$ and 
carotenoid contents in the leaves were expressed in $\mathrm{mg} \mathrm{g}^{-1}$ of fresh matter - FM ( $\left.\mathrm{mg} \mathrm{g}^{-1} \mathrm{FM}\right)$.

Stem diameter was measured $5 \mathrm{~cm}$ above the collar, with a digital caliper. Leaf area was obtained by measuring the length and width of all leaves of the plants, following the methodology described by Cavalcante et al. (2002), according to Eq 4:

$\mathrm{LA}=\sum 0.81 \mathrm{x}$

Where: LA - Leaf area $\left(\mathrm{cm}^{2}\right)$ and $\mathrm{x}$ - Product of length by width $\left(\mathrm{cm}^{2}\right)$.

Plant height was obtained by measuring the length of the aerial part, in centimeters, from the soil level (plant collar) to the insertion of the apical meristem.

The data were subjected to the analysis of variance by $F$ test and, when significant, polynomial regression analysis was performed for the factors salinity levels and potassium doses (at 0.05 probability level) and, when there was significant interaction between factors, salinity levels were further analyzed considering each potassium dose, using the statistical program SISVAR-ESAL.

\section{RESULTS AND DISCUSSION}

According to the analysis of variance summary (Table 2), there was significant effect of water salinity levels on the stomatal conductance $(g s)$ transpiration $(E)$, intercellular $\mathrm{CO}_{2}$ concentration $(\mathrm{Ci}), \mathrm{CO}_{2}$ assimilation rate $(A)$, instantaneous carboxylation efficiency (CEi) of 'BRS Rubi do Cerrado' passion fruit plants. Potassium doses had significant influence only on $A$ and CEi. The interaction between factors (SL x KD) did not cause a significant effect on any of the variables analyzed, at 40 DAS.

Table 2. Summary of analysis of variance for stomatal conductance $(g s)$, transpiration $(E)$, intercellular $\mathrm{CO}_{2}$ concentration $(C i), \mathrm{CO}_{2}$ assimilation rate $(A)$, instantaneous carboxylation efficiency (CEi) and intrinsic water use efficiency (WUEi) of 'BRS Rubi do Cerrado' passion fruit plants cultivated with saline waters and potassium doses, at 40 days after sowing (DAS).

\begin{tabular}{lccccccc}
\hline \multirow{2}{*}{ Source of variation } & \multirow{2}{*}{ DF } & \multicolumn{7}{c}{ Mean squares } \\
\cline { 3 - 7 } & & $g S$ & $E$ & $C i$ & $A$ & CEi & WUEi \\
\hline Saline levels (SL) & 4 & $0.01^{* *}$ & $1.81^{* *}$ & $3406.72^{*}$ & $16.15^{* *}$ & $0.0003^{* *}$ & $27.51^{\text {ns }}$ \\
$\quad$ Linear regression & 1 & $0.04^{* *}$ & $6.77^{* *}$ & $10245.32^{*}$ & $56.40^{* *}$ & $0.001^{* *}$ & $74.21^{\text {ns }}$ \\
Quadratic regression & 1 & $0.002^{*}$ & $0.11^{\text {ns }}$ & $1933.35^{\text {ns }}$ & $7.48^{*}$ & $0.0001^{*}$ & $4.92^{\text {ns }}$ \\
K dose (KD) & 1 & $0.0007^{\text {ns }}$ & $0.02^{\text {ns }}$ & $810.00^{\text {ns }}$ & $11.62^{*}$ & $0.0001^{*}$ & $32.88^{\text {ns }}$ \\
Interaction (SL x KD) & 4 & $0.0005^{\text {ns }}$ & $0.24^{\text {ns }}$ & $2017.89^{\text {ns }}$ & $2.53^{\text {ns }}$ & $0.0005^{\text {ns }}$ & $15.09^{\text {ns }}$ \\
Blocks & 3 & $0.0004^{\text {ns }}$ & $0.12^{\text {ns }}$ & $617.80^{\text {ns }}$ & $0.22^{\text {ns }}$ & $0.00007^{\text {ns }}$ & $66.51^{\text {ns }}$ \\
Residual & 27 & 0.0008 & 0.19 & 1077.35 & 1.23 & 0.00001 & 29.24 \\
\hline CV (\%) & & 32.80 & 34.31 & 10.70 & 22.80 & 22.53 & 14.31 \\
\hline
\end{tabular}

$\mathrm{ns}, * *, *$ respectively not significant, significant at $\mathrm{p}<0.01$ and $\mathrm{p}<0.05 ; \mathrm{DF}-$ Degree of freedom; CV - Coefficient of variation.

The stomatal conductance of 'BRS Rubi do Cerrado' passion fruit plants decreased quadratically as the levels of irrigation water electrical conductivity increased. The regression equation (Figure 1A) shows that plants grown under ECw of $0.3 \mathrm{dS} \mathrm{m}^{-1}$ had the highest stomatal conductance (0.143 mol $\left.\mathrm{H}_{2} \mathrm{O} \mathrm{m} \mathrm{m}^{-2} \mathrm{~s}^{-1}\right)$, whereas the lowest $\mathrm{gs}$ (0.054 mol $\left.\mathrm{H}_{2} \mathrm{O} \mathrm{m}^{-2} \mathrm{~s}^{-1}\right)$ was obtained under the highest water salinity level $\left(3.5 \mathrm{dS} \mathrm{m}^{-1}\right)$. By comparing the $g s$ of plants irrigated with $3.5 \mathrm{dS} \mathrm{m}^{-1}$ water to the value of plants receiving $0.3 \mathrm{dS} \mathrm{m}^{-1}$, it is possible to note a reduction of $62.24 \%(0.089 \mathrm{~mol}$ $\left.\mathrm{H}_{2} \mathrm{O} \mathrm{m}^{-2} \mathrm{~s}^{-1}\right)$. When plants are subjected to salt stress, the primary effect is the closure of stomata, as a strategy to increase stomatal resistance to the water vapor flow from the leaves to the external atmosphere in order to keep the water potential in the leaves and avoid dehydration of guard cells, which results in restriction of the normal $\mathrm{CO}_{2}$ flow towards the carboxylation site (Silva et al., 2015). Corroborating the present study, Souza et al. (2016) in a study with citrus (scion/rootstock combinations), evaluating the effects of irrigation with saline waters (ECw: 0.6 to $3.0 \mathrm{dS} \mathrm{m}^{-1}$ ) on gas exchange, found that $\mathrm{ECW}$ from $0.6 \mathrm{dS} \mathrm{m}^{-1}$ promoted a marked reduction in stomatal conductance, at 210 days after the beginning of flowering.

Leaf transpiration (Figure 1B) of 'BRS Rubi do Cerrado' passion fruit plants decreased linearly by $18.32 \%$ per unit increase in the levels of water electrical conductivity. It can be observed through the regression equation (Figure 1B) that plants grown under ECw of $3.5 \mathrm{dS} \mathrm{m}^{-1}$ had a reduction in $E$ of $62.06 \%\left(1.163 \mathrm{mmol} \mathrm{H}_{2} \mathrm{O} \mathrm{m}^{-2} \mathrm{~s}^{-1}\right)$ compared to those receiving the lowest salinity level $\left(0.3 \mathrm{dS} \mathrm{m}^{-1}\right)$. Such reduction in $E$ is related to stomatal closure (Figure 1A), standing out as a strategy to decrease the absorption rate of toxic ions $\left(\mathrm{Na}^{+}\right.$and $\left.\mathrm{Cl}^{-}\right)$. Andrade (2018), evaluating the gas exchange of yellow passion fruit as a function of irrigation with waters of different salinity levels (ECw: 0.7 to $2.8 \mathrm{dS}$ $\mathrm{m}^{-1}$ ), also found that the increase in $\mathrm{ECW}$ levels resulted in a reduction in leaf transpiration rate, equal to $16.01 \%$ per unit increment in $\mathrm{ECW}$. 

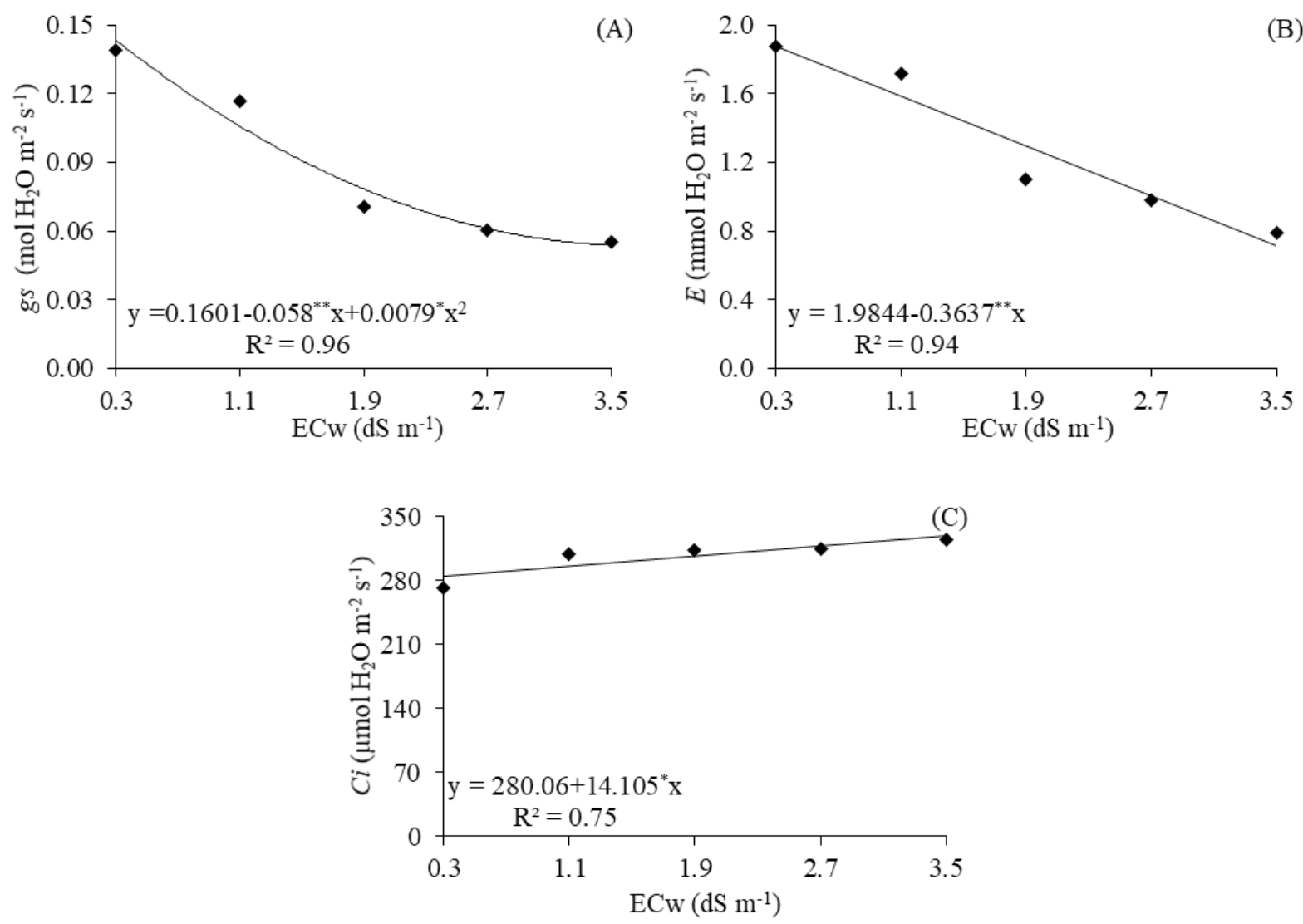

Figure 1. Stomatal conductance - gs (A), transpiration - $E$ (B) and intercellular $\mathrm{CO}_{2}$ concentration - $C i$ (C) of 'BRS Rubi do Cerrado' passion fruit plants as a function of irrigation water salinity - ECw, 40 days after sowing.

Contrary to what was observed for stomatal conductance (Figure 1A) and leaf transpiration (Figure 1B), the intercellular $\mathrm{CO}_{2}$ concentration (Figure 1C) of passion fruit plants increased linearly as a function of water salinity levels, by $5.03 \%$ per unit increase in irrigation water electrical conductivity. Comparatively, it can be noted that plants under $\mathrm{ECW}$ of $0.3 \mathrm{dS} \mathrm{m}^{-1}$ had a decrease of $13.70 \%\left(45.13 \mu \mathrm{mol} \mathrm{H}_{2} \mathrm{O} \mathrm{m}^{-2} \mathrm{~s}^{-1}\right)$ compared to those that received the highest level of water salinity. Thus, it is evidenced that, despite the reduction in stomatal conductance (Figure 1A), there was no restriction on the influx of $\mathrm{CO}_{2}$ into the substomatal cavity of the plants. According to Walter, Rosa and Streck (2015), smaller stomatal opening contributes to reduction in water losses by transpiration through the stomata, but does not compromise $\mathrm{CO}_{2}$ concentration in the leaf. In a study with passion fruit under irrigation with water of low and high salinity (ECw: 0.5 and $4.5 \mathrm{dS} \mathrm{m}^{-1}$ ), Freire et al. (2014) concluded that salt stress does not interfere with the intercellular concentration of $\mathrm{CO}_{2}$.

Irrigation water salinity negatively affected the $\mathrm{CO}_{2}$ assimilation rate of passion fruit plants. According to the regression equation (Figure 2B), it can be noted that the best fit to the data was obtained with the quadratic model, whose maximum estimated value for $A$ was $7.072 \mu \mathrm{mol} \mathrm{m} \mathrm{m}^{-2} \mathrm{~s}^{-1}$,

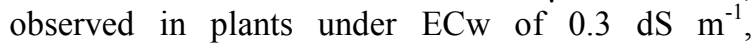

decreasing sharply from this salinity level and reaching the minimum value of $3.713 \mu \mathrm{mol} \mathrm{m}^{-2} \mathrm{~s}^{-1}$ in plants cultivated under water salinity of $3.5 \mathrm{dS} \mathrm{m}^{-1}$. There was a reduction of $47.49 \%$ in the $\mathrm{CO}_{2}$ assimilation rate of plants irrigated using water with ECw of $3.5 \mathrm{dS} \mathrm{m}^{-1}$ compared to those under $0.3 \mathrm{dS}$ $\mathrm{m}^{-1}$. The reduction of $\mathrm{CO}_{2}$ assimilation rate in passion fruit plants (Figure 2A) may be related to the action of factors of non-stomatal origin, considering that there was no reduction in the intercellular $\mathrm{CO}_{2}$ concentration in the substomatal cavity (Figure 1C). In addition, the unavailability of ATP and NADPH in the Calvin cycle and inhibition of ribulose-1,5bisphosphate carboxylase/oxygenase stand out as the main factors responsible for the reduction in $\mathrm{CO}_{2}$ assimilation rate (Machado et al., 2005). Evaluating the effects of salt stress on the West Indian cherry cv. 'BRS 366 Jaburu', Dias et al. (2019) found that the increase in water salinity from 0.8 to $3.8 \mathrm{dS} \mathrm{m}^{-1}$ caused reduction in the $\mathrm{CO}_{2}$ assimilation rate of $49.13 \%\left(3.53 \mu \mathrm{mol} \mathrm{m} \mathrm{s}^{-1}\right)$.

Potassium doses significantly influenced the $\mathrm{CO}_{2}$ assimilation rate of 'BRS Rubi do Cerrado' passion fruit plants (Table 2). According to the means comparison test (Figure 2B), the $\mathrm{CO}_{2}$ assimilation rate of plants grown under $\mathrm{K}_{2} \mathrm{O}$ dose of $100 \%$ of the recommendation differed statistically from those receiving $50 \%$ of the $\mathrm{K}_{2} \mathrm{O}$ recommendation. A reduction of $19.91 \% \quad(1.078$ 
$\mu \mathrm{mol} \mathrm{m} \mathrm{m}^{-2} \mathrm{~s}^{-1}$ ) in $A$ was observed between the lowest and highest doses of $\mathrm{K}_{2} \mathrm{O}$. Despite the functions performed by potassium in the maintenance of ionic balance and turgor of cells, through the control of stomatal opening and closure (GURGEL; GHEYI; OLIVEIRA, 2010), in this study the highest dose of $\mathrm{K}_{2} \mathrm{O}$ contributed to a reduction in the $\mathrm{CO}_{2}$ assimilation rate of passion fruit plants. This

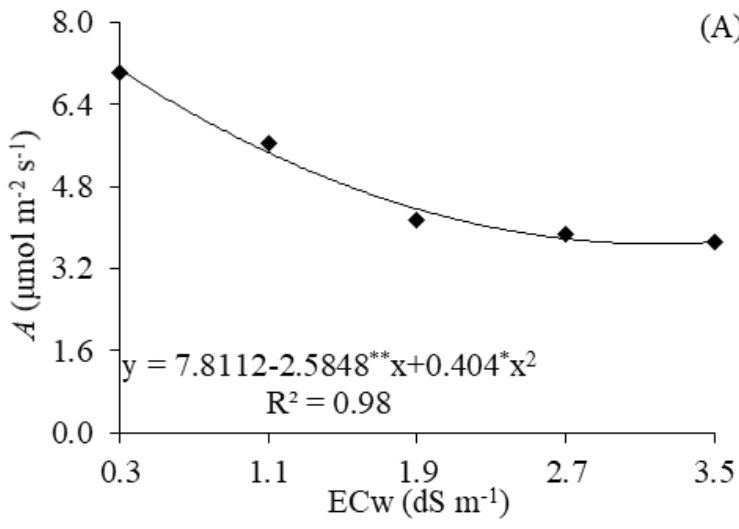

situation may be related to the source of potassium used in this study $(\mathrm{KCl})$, as this fertilizer has a high salt index (116.3) and, when associated with the use of waters with high salt concentrations, it may have induced a reduction in the osmotic potential of the soil solution, hampering the absorption of water and nutrients by plants.

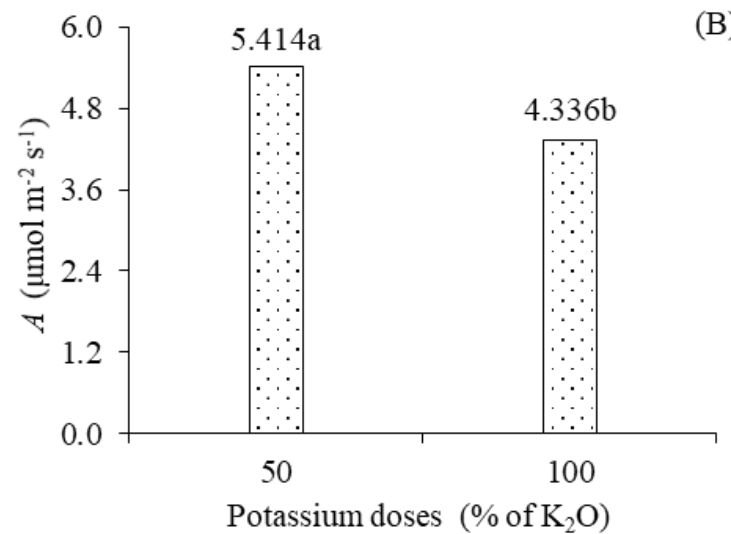

Means followed by the same letter do not differ by Tukey test $(\mathrm{p}<0.05)$. The potassium dose relative to $100 \%$ of the recommendation corresponded to $150 \mathrm{mg} \mathrm{K}_{2} \mathrm{O} \mathrm{kg}^{-1}$ of soil.

Figure 2. $\mathrm{CO}_{2}$ assimilation rate $-A$ of 'BRS Rubi do Cerrado' passion fruit plants as a function of irrigation water salinity $\mathrm{ECw}(\mathrm{A})$ and potassium doses (B), at 40 days after sowing.

The instantaneous carboxylation efficiency of passion fruit plants decreased quadratically due to salt stress. Based on the regression equation (Figure $3 \mathrm{~A})$, the highest estimated CEi of $0.0251\left(\mu \mathrm{mol} \mathrm{m} \mathrm{m}^{-2} \mathrm{~s}\right.$ ${ }^{-1} / \mu \mathrm{mol} \mathrm{m} \mathrm{m}^{-2} \mathrm{~s}^{-1}$ ) was obtained in plants grown under $\mathrm{ECw}$ of $0.3 \mathrm{dS} \mathrm{m}^{-1}$. On the other hand, the lowest CEi $\left(\mu \mathrm{mol} \mathrm{m} \mathrm{m}^{-2} \mathrm{~s}^{-1} / \mu \mathrm{mol} \mathrm{m} \mathrm{m}^{-2} \mathrm{~s}^{-1}\right)$ was observed under water electrical conductivity of $3.5 \mathrm{dS} \mathrm{m}^{-1}$. It can also be noted that passion fruit plants irrigated with $3.5 \mathrm{dS} \mathrm{m}^{-1}$ water reduced their CEi by $55.8 \%$ or $0.014\left(\mu \mathrm{mol} \mathrm{m} \mathrm{m}^{-2} \mathrm{~s}^{-1} / \mu \mathrm{mol} \mathrm{m} \mathrm{m}^{-2} \mathrm{~s}^{-1}\right.$ ), compared to those under the lowest level of water salinity $\left(0.3 \mathrm{dS} \mathrm{m}^{-1}\right)$. In plants grown under salt stress conditions, the

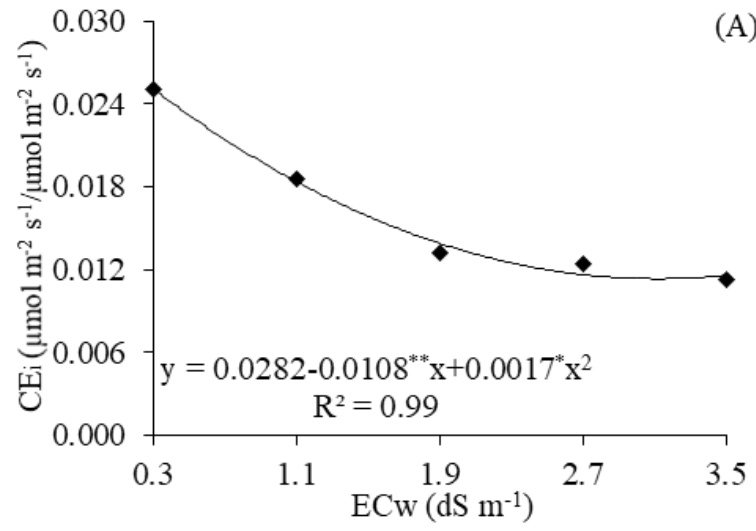

reduction in $\mathrm{CEi}$ may be related to metabolic restrictions in the Calvin cycle (SOUSA et al., 2016) and the occurrence of non-stomatal factors acting on the photosynthetic apparatus of passion fruit plants, such as inhibition of the enzymatic activity of Ribulose-1,5-bisphosphate carboxylase/oxygenase, due to the reduced availability of ATP and NADPH (MACHADO et al., 2005; SÁ et al., 2017). In a study with West Indian cherry, cv. 'BRS 366 Jaburu', under salt stress conditions (ECw of 0.8 and $3.8 \mathrm{dS} \mathrm{m}^{-1}$ ), Dias et al. (2018) found a reduction of $56.75 \%$ in CEi between plants irrigated with ECw of 0.8 and $3.8 \mathrm{dS} \mathrm{m}^{-1}$.

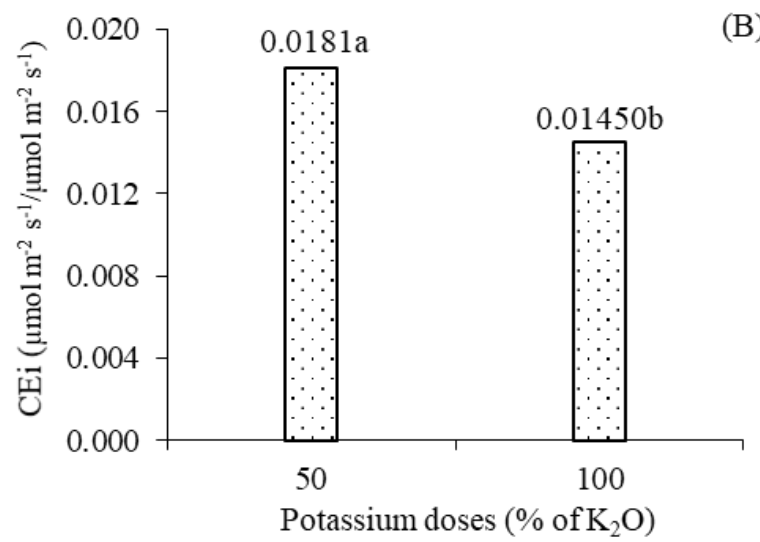

Means followed by the same letter do not differ by Tukey test $(\mathrm{p}<0.05)$. The potassium dose relative to $100 \%$ of the recommendation corresponded to $150 \mathrm{mg} \mathrm{K}_{2} \mathrm{O} \mathrm{kg}^{-1}$ of soil.

Figure 3. Instantaneous carboxylation efficiency - CEi of 'BRS Rubi do Cerrado' passion fruit plants as a function of irrigation water salinity $-\mathrm{ECw}(\mathrm{A})$ and potassium doses (B), at 40 days after sowing. 
By analyzing the instantaneous carboxylation efficiency of passion fruit as a function of potassium doses at 40 DAS, it was observed that the CEi was statistically higher in plants grown under the lowest dose of $\mathrm{K}_{2} \mathrm{O}$ than in those under $100 \%$ of the fertilization recommended by Novais, Neves and Barros (1991). There was a reduction of 0.0036 $\left(\mu \mathrm{mol} \mathrm{m} \mathrm{m}^{-2} \mathrm{~s}^{-1} / \mu \mathrm{mol} \mathrm{m} \mathrm{s}^{-2} \mathrm{~s}^{-1}\right.$ ) or $19.89 \%$ in the CEi of the plants fertilized with $100 \% \mathrm{~K}_{2} \mathrm{O}$ compared to those under the dose of $50 \% \mathrm{~K}_{2} \mathrm{O}$. Although the value recommended by Novais, Neves and Barros (1991) was supplied at the highest dose of $\mathrm{K}_{2} \mathrm{O}$ (150 $\mathrm{mg} \mathrm{kg}{ }^{-1}$ of soil), the availability of potassium in the soil solution in greater amount than the nutritional need of the crop may interfere in the absorption of $\mathrm{Ca}^{2+}$ and $\mathrm{Mg}^{2+}$ ions, due to the competition of these elements for the same absorption sites in the root tissues of plants, inducing deficiency of calcium and magnesium (SILVA; TREVIZAM, 2015). Thus, the action of non-stomatal factors such as nutritional deficiency stands out as a limiting factor for reduction in the instantaneous carboxylation efficiency of plants under salt stress conditions.

According to the analysis of variance summary (Table 3), there was significant effect $(p<0.01)$ of salinity levels on the contents of chlorophyll $a$ (Chl $a)$, chlorophyll $b(\mathrm{Chl} b)$ and carotenoids (Car), plant height $(\mathrm{PH})$, stem diameter (SD) and leaf area (LA) of passion fruit plants, at 40 DAS. There was a significant effect $(p<0.05)$ of potassium doses on Chl $a$. The interaction between factors $(\mathrm{SL} \times \mathrm{KD})$ significantly influenced $(\mathrm{p}<0.05)$ the contents of chlorophyll $a$ and $b$.

Table 3. Summary of analysis of variance for the contents of chlorophyll $a(\mathrm{Chl} a)$, chlorophyll $b(\mathrm{Chl} b)$, carotenoids (Car), plant height (PH), stem diameter (SD) and leaf area (LA) of 'BRS Rubi do Cerrado' passion fruit plants cultivated with saline water and potassium doses, at 40 days after sowing (DAS).

\begin{tabular}{lccccccc}
\hline \multirow{2}{*}{ Source of variation } & \multirow{2}{*}{ DF } & \multicolumn{7}{c}{ Mean squares } \\
\cline { 3 - 7 } & & Chl $a$ & Chl b & Car & PH & SD & LA \\
\hline Saline levels (SL) & 4 & $142.46^{* *}$ & $14.32^{* *}$ & $10.10^{* *}$ & $1008.55^{* *}$ & $2.14^{* *}$ & $55787.82^{* *}$ \\
$\quad$ Linear regression & 1 & $546.02^{* *}$ & $53.08^{* *}$ & $40.15^{* *}$ & $3413.10^{* *}$ & $8.52^{* *}$ & $206033.63^{* *}$ \\
Quadratic regression & 1 & $6.05^{\text {ns }}$ & $2.56^{\text {ns }}$ & $0.11^{\text {ns }}$ & $562.95^{*}$ & $0.002^{\text {ns }}$ & $12898.18^{\text {ns }}$ \\
K dose (KD) & 1 & $28.56^{*}$ & $0.91^{\text {ns }}$ & $0.02^{\text {ns }}$ & $0.61^{\text {ns }}$ & $0.16^{\text {ns }}$ & $12304.41^{\text {ns }}$ \\
Interaction (SL x KD) & 4 & $35.59^{*}$ & $4.49^{*}$ & $1.60^{\mathrm{ns}}$ & $47.51^{\text {ns }}$ & $0.03^{\text {ns }}$ & $26092.66^{\text {ns }}$ \\
Blocks & 3 & $10.21^{\text {ns }}$ & $0.11^{\text {ns }}$ & $0.60^{\text {ns }}$ & $159.65^{\text {ns }}$ & $0.24^{\text {ns }}$ & $68644.12^{\text {ns }}$ \\
Residual & 27 & 4.18 & 0.83 & 0.66 & 61.84 & 0.20 & 19879.39 \\
\hline CV (\%) & & 18.21 & 25.40 & 20.40 & 26.56 & 13.06 & 28.69 \\
\hline
\end{tabular}

$\mathrm{ns}, * *, *$ respectively not significant, significant at $\mathrm{p}<0.01$ and $\mathrm{p}<0.05$; DF - Degree of freedom; CV Coefficient of variation.

The chlorophyll $a$ content of the passion fruit was significantly affected by the interaction between factors (SL $x \mathrm{KD}$ ), at 40 DAS. According to regression equations (Figure 4A), a quadratic model fitted to the Chl $a$ contents of plants fertilized with 50 and $100 \%$ of the recommendation of $\mathrm{K}_{2} \mathrm{O}$. For passion fruit plants fertilized with $50 \% \mathrm{~K}_{2} \mathrm{O}$, the maximum value for $\mathrm{Chl} a\left(15.15 \mathrm{mg} \mathrm{g}^{-1} \mathrm{FM}\right)$ was obtained when they were subjected to ECw of $0.7 \mathrm{dS}$ $\mathrm{m}^{-1}$, with reduction in this variable from this salinity level, and the lowest $\mathrm{Chl} a$ content $\left(6.354 \mathrm{mg} \mathrm{g}^{-1}\right.$ FM) was found in plants irrigated using water with salinity of $3.5 \mathrm{dS} \mathrm{m}^{-1}$. On the other hand, when passion fruit plants were grown under a dose of $\mathrm{K}_{2} \mathrm{O}$ of $100 \%$, the highest $\mathrm{Chl} a$ content $\left(16.166 \mathrm{mg} \mathrm{g}^{-1}\right.$ FM) was observed under ECw of $0.3 \mathrm{dS} \mathrm{m}^{-1}$, and the minimum estimated value $\left(5.124 \mathrm{mg} \mathrm{g}^{-1} \mathrm{FM}\right)$ was observed in those receiving the highest salinity level $\left(3.5 \mathrm{dS} \mathrm{m}^{-1}\right)$. The deleterious effect on chlorophyll $a$ synthesis was more pronounced when the $\mathrm{K}_{2} \mathrm{O}$ dose increased, reinforcing the saline character of the fertilizer and the excess of salts in the water.

The reduction in chlorophyll $a$ content in passion fruit plants may be related to the oxidative stress caused by reactive oxygen species in the metabolism, due to the photo-oxidation of pigments, associated with the degradation of chlorophyll molecules (SILVA et al., 2016). In addition, salt stress stimulates the enzymatic activity of chlorophyllase, which degrades the molecules of the photosynthesizing pigment and induces the structural destruction of chloroplasts, also causing imbalance and loss of activity of pigmentation proteins (MUNNS; TESTER, 2008). Cavalcante et al. (2011) in a study aimed at determining the effects of different electrical conductivities of irrigation water (ECw from 0.5 to $4.5 \mathrm{dS} \mathrm{m} \mathrm{m}^{-1}$ ) on the contents of photosynthetic pigments, found that the increase in the salt concentration of irrigation water reduced the chlorophyll $a$ synthesis of passion fruit.

The chlorophyll $b$ content of passion fruit was also significantly influenced by the interaction between salinity levels and potassium doses. According to the regression equations (Figure 4B), the quadratic model fitted best to the data. When the $\mathrm{K}_{2} \mathrm{O}$ dose of $50 \%$ was used, the highest $\mathrm{Chl} b$ content (4.80 $\mathrm{mg} \mathrm{g}^{-1} \mathrm{FM}$ ) was obtained in plants under irrigation with $\mathrm{ECW}$ of $3.5 \mathrm{dS} \mathrm{m}^{-1}$. In plants subjected to the $\mathrm{K}_{2} \mathrm{O}$ dose of $100 \%$, the maximum estimated value was $4.969 \mathrm{mg} \mathrm{g}^{-1} \mathrm{FM}$, obtained 
under water salinity of $2.1 \mathrm{dS} \mathrm{m}^{-1}$. The increase in chlorophyll $b$ biosynthesis by plants under salt stress conditions is an adaptive response, as this pigment helps broaden the light absorption range and transfers it to chlorophyll $a$, which effectively acts on the photochemical reactions of photosynthesis, making light capture more efficient (LIMA et al.,
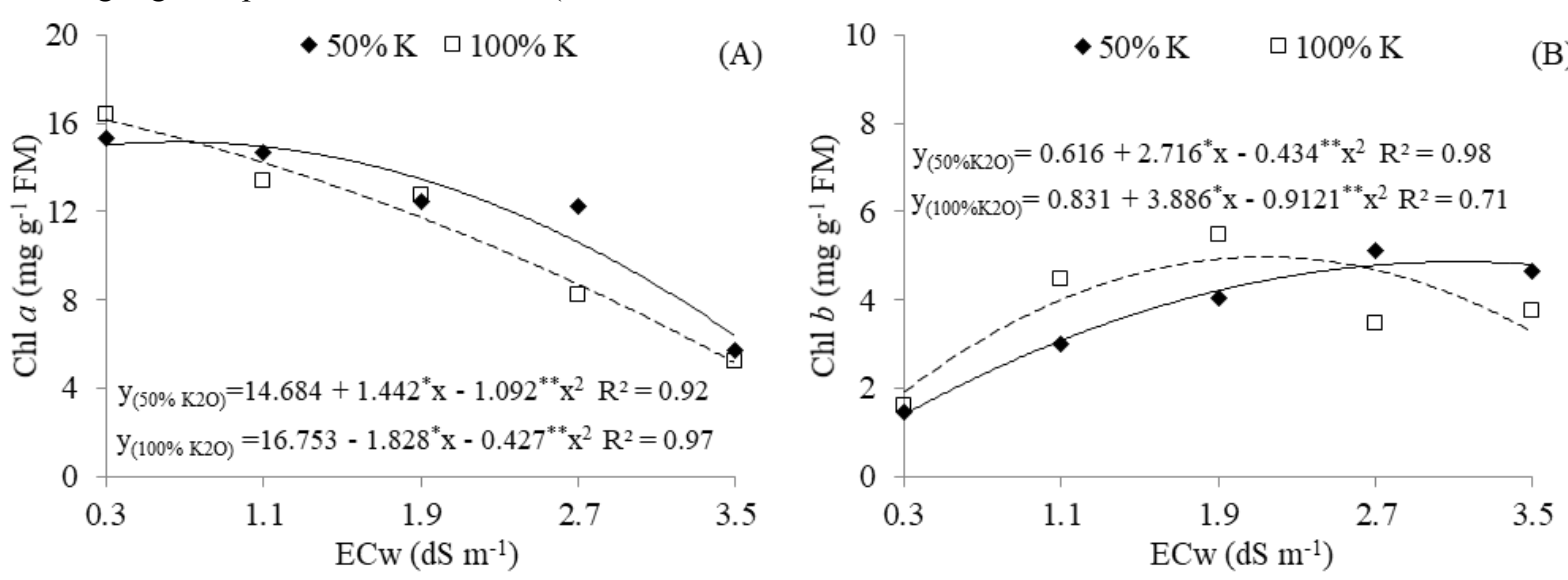

2011). Lima et al. (2018) in a study evaluating the effects of salt stress (ECw of 0.8 and $3.8 \mathrm{dS} \mathrm{m}^{-1}$ ) on the photosynthetic pigments of West Indian cherry, concluded that irrigation with high-salinity water stimulates the biosynthesis of chlorophyll $b$ and carotenoids.

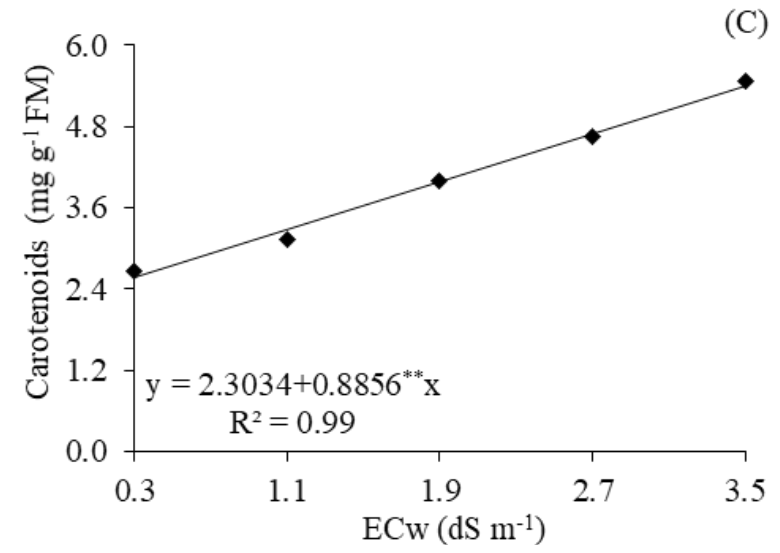

Figure 4. Contents of chlorophyll $a-\mathrm{Chl} a(\mathrm{~A})$ and chlorophyll - $\mathrm{Chl} b(\mathrm{~B})$ as a function of the interaction between water salinity levels - ECw and potassium doses, and content of carotenoids - Car (C) of 'BRS Rubi do Cerrado' passion fruit plants as a function of irrigation water salinity $-\mathrm{ECw}$, at 40 days after sowing.

The carotenoid content of passion fruit plants increased linearly with irrigation water salinity, at 40 DAS and, according to the regression equation (Figure 4C), there was an increase of $38.44 \%$ per unit increment in $\mathrm{ECw}$, that is, the synthesis of carotenoids in plants irrigated with $\mathrm{ECW}$ of $3.5 \mathrm{dS} \mathrm{m}^{-1}$ increased by $2.83 \mathrm{mg} \mathrm{g}^{-1} \mathrm{FM}$ in comparison to those under water salinity of $0.3 \mathrm{dS} \mathrm{m}^{-}$ 1 . The increase in carotenoid biosynthesis by passion fruit plants stands out as a strategy to protect the antenna complex, since they act as reducing agents and protect pigments from oxidative reactions (MELO; SOUZA; CUNHA, 2017). Unlike the results obtained in the present study, Freire and Nascimento (2018), when determining the effects of irrigation with low-salinity $\left(0.5 \mathrm{dS} \mathrm{m}^{-1}\right)$ and highsalinity $\left(4.5 \mathrm{dS} \mathrm{m} \mathrm{m}^{-1}\right)$ water on the contents of photosynthesizing pigments in yellow passion fruit, found that the lowest carotenoid contents were obtained in plants irrigated with $4.5 \mathrm{dS} \mathrm{m}^{-1}$ water.
Passion fruit plant height was negatively affected by the increase in the levels of water electrical conductivity. According to the regression equation (Figure 5A), the highest growth in $\mathrm{PH}$ was observed in plants subjected to ECw of $0.3 \mathrm{dS} \mathrm{m}^{-1}$ $(47.15 \mathrm{~cm})$. Plants grown under water salinity of $3.5 \mathrm{dS} \mathrm{m}^{-1}$ had the largest reduction in $\mathrm{PH}$, equal to $26.126 \mathrm{~cm}$ compared to those under irrigation using water with the lowest salinity level $\left(0.3 \mathrm{dS} \mathrm{m}^{-1}\right)$. The reduction in the height of passion fruit plants as a function of the increase in water salinity may be related to the reduction in the soil matric potential, which causes restriction in water absorption by plants. In addition, the increase of osmotic pressure in the soil may reach values at which plants will not have sufficient suction forces to overcome soil potential, and the consequence of such increase in the salinity of the soil solution is the reduction in water availability and absorption, reducing cell division and elongation, resulting in decrease of 
growth in plant height (GRACIANO et al., 2011). Evaluating the growth of two passion fruit cultivars (yellow and purple) as a function of irrigation with waters of different salinities, Freire and Nascimento
(2018) concluded that the height of passion fruit plants, regardless of genotype, was negatively affected by irrigation with high-salinity water $\left(3.5 \mathrm{dS} \mathrm{m}^{-1}\right)$.
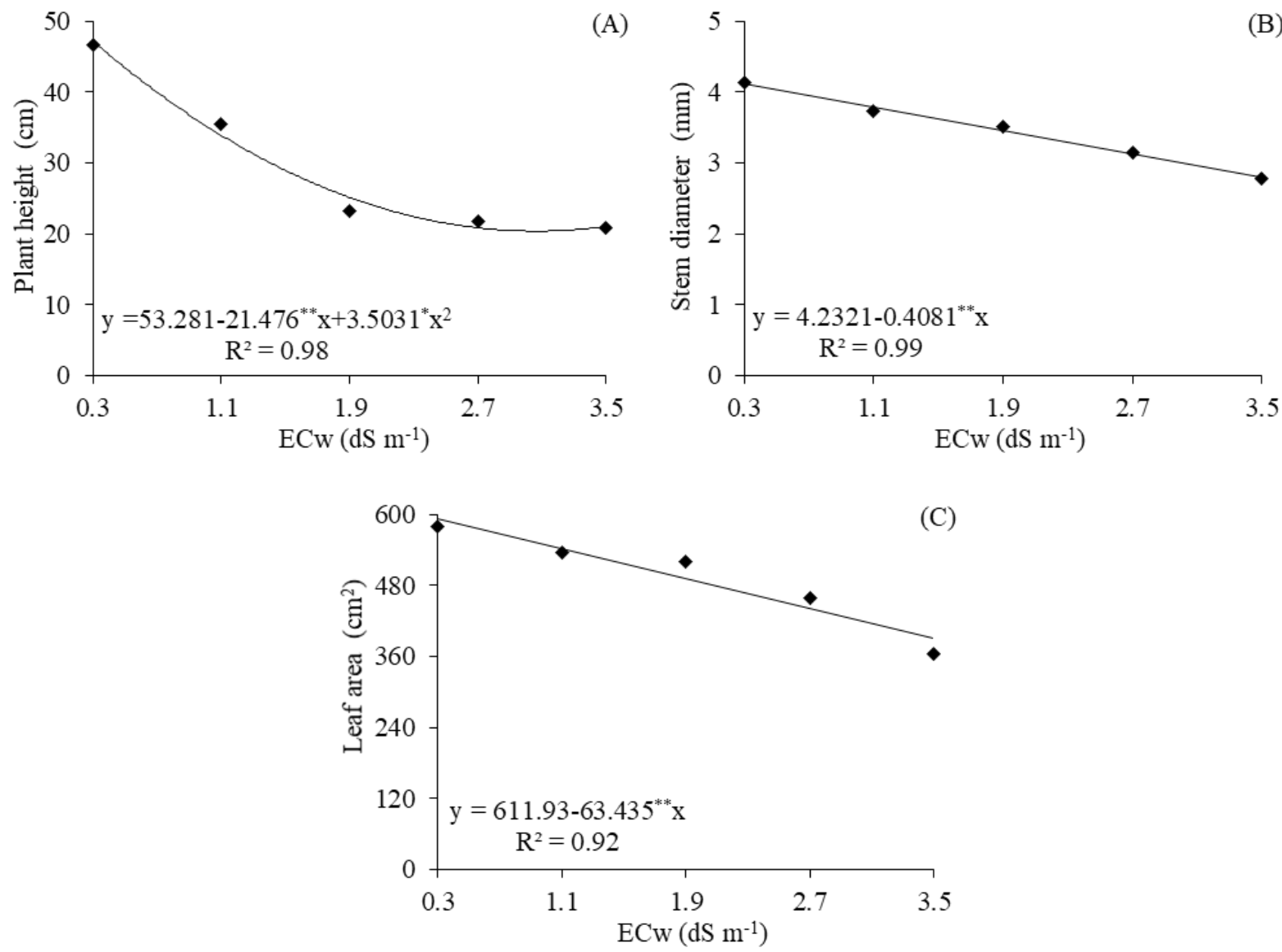

Figure 5. Plant height (A), stem diameter (B) and leaf area (C) of 'BRS Rubi do Cerrado' passion fruit plants as a function of irrigation water salinity - ECw (A) and potassium doses (B), at 40 days after sowing.

The stem diameter of passion fruit plants decreased linearly in response to increasing levels of water salinity. According to the regression equation (Figure 5B), there were reductions of $9.64 \%$ per unit increment in $\mathrm{ECw}$, i.e., a reduction of $31.77 \%$ (1.305 $\mathrm{mm}$ ) in the SD of plants irrigated with $3.5 \mathrm{dS} \mathrm{m}^{-1}$ water, compared to those subjected to $0.3 \mathrm{dS} \mathrm{m}^{-1}$. The inhibition of growth in stem diameter is a result of the changes that occurred in stomatal conductance (Figure 1A), transpiration (Figure 1B) and $\mathrm{CO}_{2}$ assimilation rate due to the reduction in the rate of water absorption by plants. According to Bezerra et al. (2016) under salt stress conditions, plants undergo inhibition of growth, due to the water deficit caused by excess soluble salts in the root zone, which leads to a reduction in cell turgor, consequently reducing cell expansion and reducing plant growth. Cavalcante et al. (2009), when evaluating the initial growth of yellow passion fruit seedlings subjected to water salinity levels (ECw: 0.4 to and $4.0 \mathrm{dS} \mathrm{m}^{-1}$ ), concluded that the increase in the electrical conductivity of irrigation water significantly increased the saline character of the substrates, resulting in reduction of growth in stem diameter, at 60 days after sowing.

It can be observed in Figure 5C that the increase in irrigation water salinity resulted in reduction in the LA of passion fruit plants, at 40 DAS, a decrease of $10.36 \%$ per unit increase in $\mathrm{ECw}$. According to the regression equation (Figure $5 \mathrm{C}$ ), when plants were subjected to irrigation with $3.5 \mathrm{dS} \mathrm{m}^{-1}$ water, their LA decreased by $44.404 \mathrm{~cm}^{2}$ in comparison to those under electrical conductivity of $0.3 \mathrm{dS} \mathrm{m}^{-1}$. Inhibition of leaf expansion in plants, caused by salt stress, is associated with a decrease in the osmotic potential of the soil solution and its restriction on water and nutrient flow in the soilplant-atmosphere direction, causing morphological and anatomical changes in the plant (BEZERRA et al., 2018). Reduction in leaf area stands out as a mechanism of tolerance of plants to salt stress and an alternative to maintain cell turgor, reducing water losses by transpiration and, consequently, reducing the transport of toxic ions such as $\mathrm{Na}^{+}$and $\mathrm{Cl}^{-}$in the xylem (OLIVEIRA et al., 2011). Studies conducted with soursop (VELOSO et al., 2019) and guava 
(BEZERRA et al., 2018) have also reported that the increase in water salinity caused reduction in leaf area.

\section{CONCLUSIONS}

Water salinity from $0.3 \mathrm{dS} \mathrm{m} \mathrm{m}^{-1}$ reduces stomatal opening, transpiration, $\mathrm{CO}_{2}$ assimilation and inhibits the growth of 'BRS Rubi do Cerrado' passion fruit plants, at 40 days after sowing.

Reduction in the instantaneous carboxylation efficiency of passion fruit is related to the action of non-stomatal factors, as there is no $\mathrm{CO}_{2}$ restriction in the substomatal cavity.

The dose of $150 \mathrm{mg} \mathrm{K} \mathrm{K}_{2} \mathrm{O} \mathrm{kg}$ of soil, corresponding to $100 \%$, intensifies the effect of salt stress on the assimilation rate and the instantaneous carboxylation efficiency of 'BRS Rubi do Cerrado' passion fruit.

There is interaction between water salinity levels and potassium doses for chlorophyll $a$ and $b$ contents in 'BRS Rubi do Cerrado' passion fruit.

\section{ACKNOWLEDGMENTS}

To $\mathrm{CNPq}$ for providing the financial aid (Proc. CNPq 429732/2018-0) and research productivity grant for the first author.

\section{REFERENCES}

ANDRADE, E. M. G Águas salinas e aplicação foliar de peróxido de hidrogênio no cultivo de maracujazeiro amarelo. 2018. 104p. Tese (Doutorado em Engenharia Agrícola: Área de concentração Irrigação e Drenagem). Universidade Federal de Campina Grande, Campina Grande, 2018.

AREF, F.; RAD, H. E. Physiological characterization of rice under salinity stress during vegetative and reproductive stages. Indian Journal of Science and Technology, 5: 2578-2586, 2012.

ARNON, D. I. Copper enzymes in isolated cloroplasts: polyphenoloxidases in Beta vulgaris. Plant Physiology, 24: 1-15, 1949.

BEZERRA, I. L. et al. Interaction between soil salinity and nitrogen on growth and gaseous exchanges in guava. Revista Ambiente \& Água, 13: e2130, 2018.

BEZERRA, J. D. et al. Crescimento de dois genótipos de maracujazeiro-amarelo sob condições de salinidade. Revista Ceres, 63: 502-508, 2016.
CAVALCANTE, L. F. et al. Crescimento inicial do maracujazeiro amarelo manejado em dois substratos irrigados com água salina. Irriga, 14: 504-517, 2009.

CAVALCANTE, L. F. et al. Clorofila e carotenoides em maracujazeiro-amarelo irrigado com águas salinas no solo com biofertilizante bovino. Revista Brasileira de Fruticultura, Volume Especial: 699705, 2011.

CAVALCANTE, L. F. et al. Germinação de sementes e crescimento inicial de maracujazeiros irrigados com água salina em diferentes volumes de substrato. Revista Brasileira de Fruticultura, 24: 748-751, 2002.

DIAS, A. S. et al. Gas exchanges and photochemical efficiency of West Indian cherry cultivated with saline water and potassium fertilization. Revista Brasileira de Engenharia Agrícola e Ambiental, 22: 628-633, 2018

DIAS, A. S. et al. Gas exchanges, quantum yield and photosynthetic pigments of West Indian cherry under salt stress and potassium fertilization. Revista Caatinga, 32: 429-439, 2019.

DIAS, T. J. et al. Qualidade física e produção do maracujá amarelo em solo com biofertilizante irrigado com águas salinas. Semina: Ciências Agrárias, 33: 2905-2918, 2012.

DONAGEMA, G. K. et al. Manual de métodos de análise de solos. 2. ed. rev. Rio de Janeiro, RJ: Embrapa Solos, 2011. 230p. (Embrapa Solos. Documentos, 132).

EMPRESA BRASILEIRA DE PESQUISA AGROPECUÁRIA - EMBRAPA. BRS Rubi do Cerrado: Hibrido de maracujazeiro-azedo de frutos avermelhados e amarelos para indústria e mesa. 2 ed. Brasília, DF: EMBRAPA CERRADO, 2012. 2 p.

FREIRE, J. L. O. et al. Crescimento do maracujazeiro amarelo sob estresse salino e biofertilização em ambiente protegido contra perdas hídricas. Holos, 4: 55-68, 2012.

FREIRE, J. L. O. et al. Rendimento quântico e trocas gasosas em maracujazeiro amarelo sob salinidade hídrica, biofertilização e cobertura morta. Revista Ciência Agronômica, 45: 82-91, 2014.

FREIRE, J. L. O.; NASCIMENTO, G. S. Produção de mudas de maracujazeiros amarelo e roxo irrigadas com águas salinas e uso de urina de vaca. Revista de Ciências Agrárias, 41: 981-988, 2018. 
GRACIANO, E. S. A. et al. Crescimento e capacidade fotossintética da cultivar de amendoim BR 1 sob condições de salinidade. Revista Brasileira de Engenharia Agrícola e Ambiental, 15: 794-800, 2011.

GURGEL, M. T.; GHEYI, H. R.; OLIVEIRA, F. H. $\mathrm{T}$. Acúmulo de matéria seca e nutrientes em meloeiro produzido sob estresse salino e doses de potássio. Revista Ciência Agronômica, 41: 18-28, 2010.

HASANUZZAMAN, M. et al. Potassium: A vital regulator of plant responses and tolerance to abiotic stresses. Agronomy, 31: 1-29, 2018.

INSTITUTO BRASILEIRO DE GEOGRAFIA E ESTATÍSTICA - IBGE, Produção agrícola: Lavoura Permanente. 2018. Disponível em: $<$ https://cidades.ibge.gov.br/brasil/ pesquisa/15/11863>. Acesso em: 28 novembro. 2019.

JIANG, J. et al. Effect of irrigation amount and water salinity on water consumption and water productivity of spring wheat in Northwest China. Field Crops Research, 137: 78-88, 2012.

LIMA, G. S. et al. Effects of saline water and potassium fertilization on photosynthetic pigments, growth and production of West Indian cherry. Revista Ambiente \& Água, 13: e2164, 2018.

LIMA, M. C. et al. Crescimento e produção de pigmentos fotossintéticos em Achillea millefolium L. cultivada sob diferentes níveis de sombreamento e doses de nitrogênio. Ciência Rural, 41: 45-50, 2011.

MACHADO, E. C. et al. Respostas da fotossíntese de três espécies de citros a fatores ambientais. Pesquisa Agropecuária Brasileira, 40: 1161-1170, 2005.

MARSCHNER, P. Mineral nutrition of higher plants. 3 ed. San Diego: USA, Elsevier, 2012. 651 p.

MELO, H. F.; SOUZA, E. R.; CUNHA, J. C. Fluorescence of chlorophyll $a$ and photosynthetic pigments in Atriplex nummularia under abiotic stresses. Revista Brasileira de Engenharia Agrícola e Ambiental, 21: 232-237, 2017.

MUNNS, R.; TESTER M. Mechanisms of salinity tolerance. Annual Review of Plant Biology, 59: 651 $-681,2008$.

NOVAIS, R. F.; NEVES, J. C. L.; BARROS, N. F. Ensaio em ambiente controlado. In: OLIVEIRA, A.
J. et al. (Eds.). Métodos de pesquisa em fertilidade do solo. Brasília: Embrapa SEA, 1991. p. 189-253.

ODRESCA, D. Integração salinidade, biofertilizante e adubação potássica na formação de mudas de maracujazeiro amarelo. 2016. $47 \mathrm{f}$. Monografia (Graduação em Agronomia) Universidade Federal da Paraíba, Mossoró, 2016.

OLIVEIRA, F. A. et al. Desempenho de cultivares de alface submetidas a diferentes níveis de salinidade da água de irrigação. Revista Brasileira de Engenharia Agrícola e Ambiental, 15: 771-777, 2011 .

RICHARDS, L. A. Diagnosis and improvement of saline and alkali soils. Washington: U.S, Department of Agriculture, 1954. 160 p.

SILVA, A. R. A. et al. Pigmentos fotossintéticos e potencial hídrico foliar em plantas jovens de coqueiro sob estresses hídrico e salino. Revista Agro@mbiente On-line, 10: 317-325, 2016.

SILVA, F. G. et al. Trocas gasosas e fluorescência da clorofila em plantas de berinjela sob lâminas de irrigação. Revista Brasileira de Engenharia Agrícola e Ambiental, 19: 946-952, 2015.

SOUZA, L. P. et al. Formation of 'Crioula' guava rootstock under saline water irrigation and nitrogen doses. Revista Brasileira de Engenharia Agrícola e Ambiental, 20: 739-745, 2016.

VELOSO, L. L. S. A. et al. Effects of saline water and exogenous application of hydrogen peroxide $(\mathrm{H} 2 \mathrm{O} 2)$ on Soursop (Annona muricata L.) at vegetative stage. Journal of Crop Science, 13: 472-479, 2019.

VIANA, P. C. et al. Efeito da salinidade da água de irrigação na produção de maracujazeiro-amarelo. Revista Agropecuária Científica no Semiárido, 8: 45-50, 2012.

ZHANG, F. et al. Potassium nutrition of crop sunder varied regimes of nitrogen supply. Plant and Soil, 335: 21-34, 2010. 